\section{Transformational Politics Group Applies to Become Organized Section in Fall, 1990}

\section{Jeff Fishel, American University Betty H. Zisk, Boston University}

A few years ago, a small group of political scientists met at the APSA Meetings and formed a new network of scholar-teachers in the discipline called the Conference Group on Transformational Politics (CGTP). Over the past three years, interest in the CGTP's panels and support groups has grown substantially, and à sufficient number of petitions have been signed to allow it to seek Council approval for Organized Section status.

The primary aim of the proposed new Section is to reopen and reexplore some fundamental questions about emergent possibilities in the global political order, and in the relationship of political science and political scientists to that order. As we move toward the 21st century, many scholars and practitioners are questioning the validity and viability of traditional approaches and divisions in political science and political life (normative/empirical; personal/professional; theory/practice; Liberal/ Conservative; Left/Right; global/ local; secular/spiritual, to identify a few). How useful and meaningful are such divisions, such polarities in the 1990s? Or later, if and when a "post-liberal" politics truly emerges in the next 50 years? Scholars in this section are committed to examining alternatives that seek a new synthesis.

All of the original group are veterans-intellectually and/or politically-of one or more of the most important, progressive social movements of the past 35 years: feminist, civil rights, environmental, peace and nonviolent conflict-resolution, human and spiritual growth, gay and lesbian rights, libertarian, populist-democratic. Some have long histories in "left-liberal" circles, others in "conservative-humanist." Most, however, are dissatisfied with the conceptual assumptions of the classic "LeftRight" continuum, not only because of its obvious deficiencies, noted by political scientists for generations, but also because dimensions of this type are rooted in a limited political consciousness at a time when a more robust and historically appropriate new approach is long overdue.

Our members do not agree on the specific forms that such a comprehensive alternative might take (see some principles, however, detailed below). Rather, we are united in our commitment to searching and experimenting in a manner that reaches beyond the traditional discourse of contemporary political science or political life. In this search, we share aspects of a vision about human beings that one associates in modern life with Carl Rogers: that we are capable of becoming more lifeaffirming, responsible, compassionate and caring, in our professional as well as political lives.

How might such values become manifest in politics? In our research? In our teaching? In our behavior and functioning in the American Political Science Association?

The proposed Organized Section on Transformational Politics will explore these questions, on a large scale, and in the very mundane but important ways we function as political scientists, however and wherever that might be. For example, the CGTP has organized a "support group" that meets nightly at the APSA Meetings to examine whatever political/professional/personal issues participants choose. It has explored ways of keeping APSA panels intellectually alive and stimulating without reinforcing the often hypercompetitive and personally destructive behavior that characterizes much of scholarly exchange. And members have presented research in areas such as the search for a new political paradigm: Green politics; the potential role of humanistic psychology in public affairs; the contributions of eco-feminism to feminist theory in particular, social change in general; post-structural/post-modern political theory; and spiritual foundations of political transformation.

The proposed new section hopes to continue promoting a political science and a political community consistent with the following ethical imperatives (individuals in the section do not share every aspect of these principles but they are illustrative):
(1) A politics of participation that provides every member of society with full opportunities to influence the political, social and economic institutions affecting their lives, and that fosters collective and personal responsibility to fulfill that task;

(2) A politics of social justice and hope that seeks to reduce the material inequities within and between nations, and that treats the problems and scarcities before us, now and in the future, as opportunities to clarify our sense of what truly is important in life;

(3) A politics of conflict-resolution and healing that acknowledges and respects differences and goes beyond "us against them," or "right versus wrong," in promoting cooperation and community in all matters where possible;

(4) A politics of human growth that fosters the full development of each person's potential;

(5) A politics of ecology and unitive consciousness which understands that we are only one part of a seamless web of life, that we are responsible to all life on earth, and that our journey can have sacred meaning-as we comprehend that term.

We hope others will join us, and we welcome new members. For additional information, contact one of the following: Jeff Fishel, School of Public Affairs, American University, Washington, DC 20016, (202) 8856225; or Betty H. Zisk, Department of Political Science, Boston University, 232 Bay State Road, Boston, MA 02215, (617) 273-0923.

\section{Finding Jobs: Placement of Political Scientists, 1988}

\section{Sheilah Mann, American \\ Political Science Association}

One hundred and fifteen Ph.D. departments $(92 \%)$ responded to a survey on the 1988 placement class. Ninety-seven of these departments awarding Ph.D.s in political science reported having candidates in the 1988 placement class. Their responses account for $78 \%$ of the Ph.D. 
TABLE 1.

Trends in Placement*

\begin{tabular}{lrrrrrrr}
\hline & 1982 & 1983 & 1984 & 1985 & 1986 & 1987 & 1988 \\
\hline $\begin{array}{l}\text { Number of firm candidates } \\
\text { \% repeats }\end{array}$ & 611 & 523 & 672 & 715 & 690 & 604 & 740 \\
$\begin{array}{l}\text { Placement success of firm candidates } \\
\quad \% \text { ) }\end{array}$ & 62 & 41 & 38 & 37 & 32 & 36 & 32 \\
\% of placement in temporary & 79 & 72 & 70 & 69 & 72 & 69 \\
$\quad$ positions & 36 & 33 & 24 & 43 & 38 & 27 & 38 \\
\% placement of Ph.D.s & 64 & 65 & 64 & 69 & 69 & 76 & 64 \\
Placement success of Ph.D.s (\%) & 72 & 87 & 77 & 81 & 83 & 80 & 83 \\
\% of placement in nonacademic jobs & 19 & 19 & 18 & 17 & 9 & 9 & 8 \\
\hline
\end{tabular}

*Figures are estimates of total population based on samples of 91 departments for $1982(76 \%$ response rate), 87 departments in 1983 ( $73 \%$ response rate), 83 departments for 1984 ( $71 \%$ response rate), 82 departments in 1985 (68\% response rate), 83 departments for 1986 ( $70 \%$ response rate), 103 departments for 1987 ( $86 \%$ response rate), and 115 departments for 1988 ( $92 \%$ response rate).

departments. The range in the size of placement classes continues to be considerable. The University of California-Berkeley, with 59 job candidates, accounted for $8 \%$ of the placement class, which increased from 604 in 1987 to 740 in 1988, and the $24 \mathrm{Ph}$.D. departments with 10 or more job candidates collectively accounted for $59 \%$ of the placement class. Twenty-one departments had four or fewer candidates. Seventytwo departments had placement classes of five to nine job candidates.

These data collected from the recent survey on the preparation of the job candidates are not markedly different from those of previous surveys. This report begins with a review of recent surveys, along with those from previous surveys.

An interpretation of what the Association's data, collected from other studies about the future demand for faculty and reports on higher education, concludes this report.

\section{Placement Success}

The placement success of candidates for political science positions has not changed much over the years. Table 1 shows that, from 1983 onward, around $70 \%$ of the candidates have found positions. The 1982 class was somewhat less successful $(62 \%)$. But placement classes in the prior decade showed the somewhat higher success rates of recent years.

The placement success of candidates with Ph.D.s remains consistent- ly higher than that of the entire placement class and Ph.D.s continue to account for placement in the majority of positions. Table 2 shows the even greater difference in securing placement between Ph.D.s and $\mathrm{ABDs}$ to the advantage of candidates who have received their degrees. After declining last year, the proportion of placements in temporary positions rose again to $38 \%$. But, the trend toward fewer placements in non-academic positions continued with only $8 \%$ of the candidates accepting these jobs, less than half of the proportion doing so from 1981 through 1985 .

Table 3 reports on placement success by gender. In 1988, for the first time since 1984, the percentage of placement success for women with Ph.D.s was lower than that of men. On the other hand, ABD women fared better than men in the last year, just as they did in 1984 through 1986. The greater proportion of Ph.D.s placed overall is associated with $70 \%$ of the men achieving placement success compared to $67 \%$ of the women. But consistent with the 1986 and 1987 surveys, in 1988 , a smaller percentage of women $(33 \%)$ than men (39\%) took temporary jobs.

Table 4 summarizes placement success by field of specialization. Placement success for "Americanists," i.e., candidates in American government and the generally predominant American fields of public policy and public administration, continues to be relatively high and the placement success of political theorists remains
TABLE 2.

Degree Completion and Placement Success, 1984-87 (\%)

\begin{tabular}{cccc}
\hline & \multicolumn{3}{c}{ Placement Success* } \\
\cline { 2 - 4 } & Total & Men & Women \\
\hline ABD & 68 & 64 & 83 \\
1984 & 51 & 52 & 50 \\
1985 & 57 & 56 & 62 \\
1986 & 68 & 67 & 68 \\
1987 & 53 & 50 & 63 \\
1988 & & & \\
Ph.D. & 77 & 80 & 69 \\
1984 & 81 & 78 & 90 \\
1985 & 83 & 81 & 88 \\
1986 & 80 & 77 & 87 \\
1987 & 83 & 89 & 72 \\
1988 & & & \\
\hline *Placement success measures number placed \\
within each category as a percentage of the \\
total candidates within each category.
\end{tabular}

TABLE 3.

Placement of Job Candidates by Sex, 1984-87

\begin{tabular}{llll}
\hline & Total* & Men & Women \\
\hline $\begin{array}{l}\text { Number of } \\
\text { Firm Candidates }\end{array}$ & & & \\
1984 & 672 & 504 & 168 \\
1985 & 715 & 522 & 193 \\
1986 & 690 & 510 & 180 \\
1987 & 604 & 438 & 166 \\
1988 & 740 & 552 & 188 \\
Number Placed & & & \\
1984 & 485 & 365 & 119 \\
1985 & 497 & 363 & 134 \\
1986 & 477 & 344 & 133 \\
1987 & 455 & 328 & 127 \\
1988 & 512 & 389 & 126 \\
Placement & & & \\
Success (\%) & & & \\
1984 & 72 & 72 & 71 \\
1985 & 70 & 70 & 69 \\
1986 & 69 & 67 & 74 \\
1987 & 72 & 70 & 75 \\
1988 & 69 & 70 & 67 \\
Percent in & & & \\
Temporary & & & \\
Positions (\%) & & & \\
1984 & 33 & 33 & 34 \\
1985 & 43 & 43 & 43 \\
1986 & 38 & 40 & 35 \\
1987 & 27 & 29 & 24 \\
1988 & 38 & 39 & 33 \\
\hline
\end{tabular}

*Adjusted total

the lowest. While the placement success of candidates in comparative politics and international relations is somewhat lower than it was in 1987 , there is less of a difference between the placement success in these fields and those of candidates specializing 
TABLE 4.

Placement Success by Field of Specialization, 1984-87 (\%)

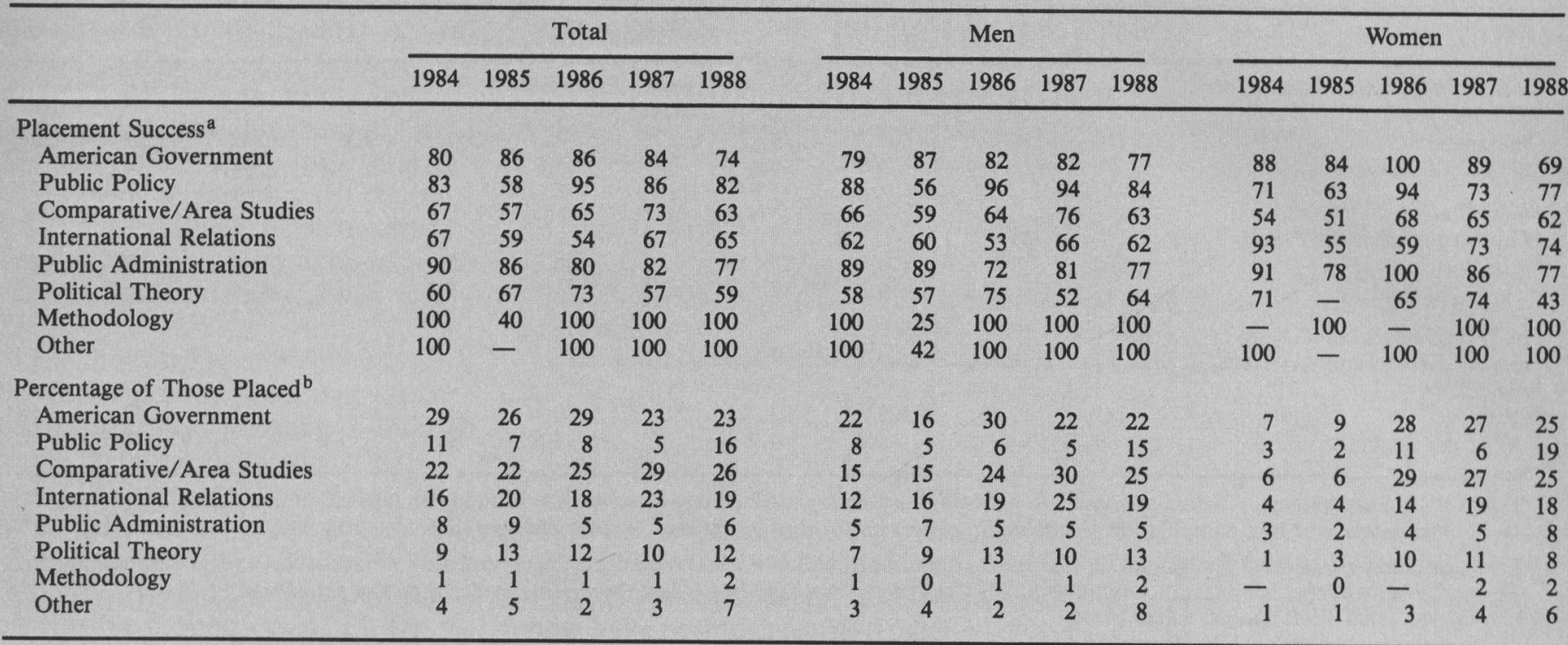

a Placement success measures number placed in a field as a percentage of total candidates in each of the respective fields.

${ }^{b}$ Percentage of those placed measures the total number placed in a particular field as a percentage of the total number placed in all fields.

in American politics than in past years. In 1988 men placed in American politics, public policy and political theory exceeded that of women. But the placement success of women was greater in international relations. There was no difference, by gender, in the fields of public administration, comparative politics and methodology.

Table 4 also shows what percentage of all of the placements is accounted for by the candidates' fields of specialization. The proportion of placements in public policy increased threefold in 1988 and the placement of candidates in "other" fields, which include interdisciplinary studies and women's studies, also increased.

Political science departments re- ported that $65 \%$ of the candidates not placed would remain at their graduate department, with two out of three of them receiving departmental support. Nine percent of the candidates were not yet employed and $7 \%$ accepted employment outside of the profession. The employment status of fully $19 \%$ of the candidates who were not placed was not certain.

Table 5 records the data on who hired members of the 1988 placement class. There is little change in their placement over the last five years. The largest proportion, $40 \%$ in 1988 , take positions in Ph.D. departments and the next largest proportion, $31 \%$, are hired by undergraduate political science departments. M.A. departments account for $17 \%$ of the placements. Very few political scientists take positions in two-year col.leges or colleges with a combined social science department. The association between gender and placement by type of institution in 1988 shows that a higher proportion of women than men accepted jobs in departments offering graduate degrees.

\section{Minority Placement and Recruitment}

There were 24 black candidates in this placement class. All were placed. There were 11 candidates with Spanish surnames and nine were placed.

In 1985, the Association began to respond to the need to recruit black students for graduate study in polit-

\section{TABLE 5.}

Placement by Type of Hiring Institution, 1984-87 (\%)

\begin{tabular}{|c|c|c|c|c|c|c|c|c|c|c|c|c|c|c|c|}
\hline & \multicolumn{5}{|c|}{ Total } & \multicolumn{5}{|c|}{ Men } & \multicolumn{5}{|c|}{ Women } \\
\hline & 1984 & 1985 & 1986 & 1987 & 1988 & 1984 & 1985 & 1986 & 1987 & 1988 & 1984 & 1985 & 1986 & 1987 & 1988 \\
\hline Ph.D. department & 37 & 37 & 41 & 41 & 40 & 36 & 38 & 41 & 40 & 39 & 40 & 35 & 41 & 44 & 44 \\
\hline M.A. department & 17 & 18 & 16 & 15 & 17 & 19 & 16 & 16 & 16 & 16 & 12 & 23 & 18 & 12 & 20 \\
\hline $\begin{array}{l}\text { Undergraduate political } \\
\text { science }\end{array}$ & 24 & 23 & 28 & 29 & 31 & 24 & 23 & 28 & 28 & 34 & 27 & 22 & 28 & 30 & 24 \\
\hline Undergraduate social science & 3 & 3 & 4 & 1 & 2 & 2 & 3 & 5 & 1 & 2 & 3 & 3 & 3 & 2 & 1 \\
\hline Two-year college & 1 & 2 & 1 & 2 & 2 & 2 & 2 & 1 & 2 & 2 & - & 1 & 1 & 2 & 2 \\
\hline Nonacademic & 18 & 17 & 9 & 12 & 8 & 18 & 18 & 9 & 13 & 8 & 19 & 16 & 9 & 10 & 9 \\
\hline Total & 100 & 100 & 99 & 100 & 100 & 101 & 100 & 100 & 100 & 100 & 101 & 100 & 100 & 100 & 101 \\
\hline
\end{tabular}


TABLE 6.

Black Students in Political Science Ph.D. Programs, 1979-90*

\begin{tabular}{|c|c|c|c|c|c|c|c|c|c|c|c|}
\hline & 1979 & 1980 & 1981 & 1982 & 1984 & 1985 & 1986 & 1987 & 1988 & 1989 & 1990 \\
\hline \multicolumn{12}{|c|}{$\begin{array}{l}\text { Black Student Enrollment in } \\
\text { Ph.D. Programs }\end{array}$} \\
\hline$\%$ of All Students & 9 & 6.9 & 6.4 & 5.8 & 4.5 & 5.6 & 5.3 & 4.7 & 4.1 & 4.6 & 5 \\
\hline \multicolumn{12}{|c|}{$\begin{array}{l}\text { Black Students Starting a } \\
\text { Ph.D. Program in the Previous Fall }\end{array}$} \\
\hline \multicolumn{12}{|c|}{$\begin{array}{l}\text { Ph.D. Degrees Granted in the } \\
\text { Previous Three Years to Black } \\
\text { Students** }\end{array}$} \\
\hline $\begin{array}{l}\text { Number } \\
\% \text { of All Students }\end{array}$ & $\begin{array}{r}142 \\
7.7\end{array}$ & $\begin{array}{r}135 \\
6.3\end{array}$ & $\begin{array}{l}125 \\
5.8\end{array}$ & $\begin{array}{c}93 \\
4.9\end{array}$ & $\begin{array}{l}80 \\
4.7\end{array}$ & $\begin{array}{l}80 \\
4.6\end{array}$ & $\begin{array}{r}91 \\
6\end{array}$ & $\begin{array}{l}74 \\
5.7\end{array}$ & $\begin{array}{l}75 \\
5.1\end{array}$ & $\begin{array}{c}67 \\
4.5\end{array}$ & $\begin{array}{c}68 \\
4.3\end{array}$ \\
\hline \multicolumn{12}{|c|}{$\begin{array}{l}\text { *Data for } 1983 \text { are missing. All data are based on APSA annual surveys of graduate departments, printed annually either in a Guide to Graduate Study } \\
\text { in Political Science or in a pamphlet on Graduate Students and Faculty in Political Science Ph.D. and M.A. Programs. }\end{array}$} \\
\hline
\end{tabular}

ical science. Association data disclose that the number and proportion of black students enrolled in Ph.D. programs and receiving doctorates is low, and declined over the last decade. Table 6 records the data on black enrollment and degree completion in political science Ph.D. programs. This decline, particularly from 1986 to 1988 , is especially disturbing because The Council of Graduate Schools has found that the proportion of blacks enrolled (generally) in graduate programs increased recently by $9 \%$ (Blum, 1990).

Association programs which seek to increase the recruitment and successful degree completion of black students include: the Ralph Bunche Summer Institute for black undergraduate students, the Black Fellow-

\section{TABLE 7.}

Undergraduate Enrollments and Degrees Awarded, 1983-88* (\%)

\begin{tabular}{lccccc}
\hline & $1983-84$ & $1984-85$ & $1985-86$ & $1986-87$ & $1987-88$ \\
\hline $\begin{array}{l}\text { Change in Total Political Science } \\
\text { Enrollment }\end{array}$ & 42 & 41 & 41 & 54 & 61 \\
$\quad$ Increase & 36 & 33 & 57 & 31 & 29 \\
$\quad$ No Change & 22 & 26 & 22 & 15 & 9 \\
$\quad$ Decrease & & & & & \\
Change in Political Science Degrees & 35 & 34 & 36 & 41 & 47 \\
Awarded & 45 & 44 & 44 & 41 & 40 \\
$\quad$ Increase & 20 & 21 & 20 & 18 & 14 \\
$\quad$ No Change & & & & & \\
$\quad$ Decrease & & & & \\
\hline *These are data from one academic year to the next and the dates represent the end of an academic \\
year, e.g., 1982-83 to 1983-84 is shown as 1983-84.
\end{tabular}

\section{Future Faculty Demand and Employment Prospects} departments, and the newly begun "Project Identification" to encourage black undergraduates to consider graduate school and assist $\mathrm{Ph} . \mathrm{D}$. departments in their efforts to recruit these students. (For a full description of the "Minority Identification Project" see Catherine E. Rudder's "Executive Director's Report" in this issue.) The Association has not yet collected comparable data for Latino/Chicano students. But mindful of their too small numbers in the profession, the APSA is working with graduate departments to initiate comparable programs to identify and recruit Latino/Chicano students for graduate school.

The optimistic outlook for political science expressed in last year's report can be sustained by current data. Political science continues to be a popular major among undergraduates: Its proportion of intended majors among this year's freshmen is $3.1 \%$, again second only to psychology $(4.1 \%)$ among the social sciences and considerably greater than other humanities and social science fields of study (Fact File, 1990). These expressions of preferences among freshmen, which have been collected now for 25 years, are very good predictors of actual selection of majors (Alexander W. Astin, et al., 1989).

Data gathered by the Association in its Annual Survey of Political Science Departments show a trend, each year, toward increasing undergraduate enrollments, degrees and "new hires" in political science. Tables 7 and 8 show these data for the last five years.

A broad study of the supply and demand for faculty in the next generation forecasts a "short fall" of faculty in the social sciences and the humanities (Bowen and Sosa, 1989). The authors predict that from 19972002 there will be fewer candidates than there are faculty positions in the humanities and social sciences in order to fill replacements and some expansion in student enrollment. The 
American Council on Education's annual survey, "Campus Trends, 1989 ," reports a steady increase in the proportion of institutions whose administrators report difficulty in finding qualified persons for fulltime faculty positions, from $25 \%$ in 1987 , to $37 \%$ in 1988 , to $50 \%$ in 1989. Social sciences are the fourth (of 7) most difficult fields to recruit for, following business, computer science and mathematics (El-Khawas, 1989).

The increased size of this year's placement class suggests that Ph.D. departments are beginning to respond to the favorable employment outlook. This increase is but a part of an overall increase in the number of doctorates awarded in all fields (Mooney, April 29, 1990). Comparable sizeable proportions of Ph.D. political science departments expect future placement classes to be larger $(40 \%)$ or the same size $(42 \%)$. Only 9\% of the Ph.D. departments anticipated smaller future classes.

Political science departments can respond positively to the indications of current and future demand for political science faculty in several ways. Undergraduate advisors should encourage their talented students to apply to graduate school. They should point out that not only is the job market healthy but that more faculty view their conditions of employment with more equanimity. A Chronicle of Higher Education story says that the greater competition for faculty is associated with better offers being made in terms of salaries, research or summer support, housing assistance (in particularly expensive markets), and efforts to accommodate or assist spouses seeking employment (Mooney, April 18, 1990).

At the same time, graduate departments are well advised to note that the Chronicle's story about the favorable job market concludes with a statement by Philip L. Quine, chairman of the American Philosophical Association's Committee on Career Opportunities, pointing out that the placement difficulties encountered by Ph.D.s in the 1970s had not been expected by their graduate departments in the previous decade. A month later The Chronicle featured a story about this "Lost

\begin{tabular}{|c|c|c|c|c|c|}
\hline & $1984-85$ & $1985-86$ & $1986-87$ & $1987-88$ & $1988-89$ \\
\hline \multicolumn{6}{|l|}{ Change in Faculty Size (\%) } \\
\hline & 12 & 16 & 16 & 20 & 22 \\
\hline Net Loss & 7 & 13 & 12 & 10 & 11 \\
\hline No Change & 81 & 72 & 72 & 66 & 62 \\
\hline \multicolumn{6}{|l|}{ Number of Faculty Hired for } \\
\hline New Positions & 80 & 77 & 86 & 147 & 158 \\
\hline \multirow{2}{*}{\multicolumn{6}{|c|}{$\begin{array}{l}\text { Number of Faculty Expected to be } \\
\text { Hired for New Positions in the } \\
\text { Coming Year }\end{array}$}} \\
\hline & 80 & 108 & 142 & 159 & 178 \\
\hline
\end{tabular}

Generation of Scholars" who failed to secure permanent faculty positions in the 1970s and are being passed over by academic departments which now have positions to fill (Heller, May 23, 1990). There are political scientists from these placement classes of the 1970s who have remained involved in the profession and in academic life and ought not to be penalized for their initial experience now that there is an expanding job market. Graduate departments might well consider their ties to such former students who are still actively seeking employment.

Restraint in the expansion of graduate admissions may also be warranted by the expected financial constraints on growth which many institutions of higher education are beginning to confront. These constraints will require institutions to make difficult choices in the allocation of resources, including not hiring new faculty or supporting some departments at the expense of others. Current faculty may well support such decisions in order to protect their salaries. Such a recommendation was made by a Cornell University faculty committee to the university's administration earlier this past academic year (McMullen, The Chronicle of Higher Education, December 6, 1989). Consequently, while the outlook for employment in political science is favorable, and talented, interested undergraduates should be recruited for the profession, Ph.D. departments need to take into account the conditions facing higher education generally, as well as the immediate job market, before making decisions about their enrollments.

\section{Note}

*The Council's report is in press. A report on the findings of a survey of 536 institutions, which include these data, was prepared by Debra E. Blum, "Representation of Minorities in Graduate Programs Rose Steadily From 1986 to 1988, Survey Finds," The Chronicle of Higher Education, May 2, 1990, p. A13.

\section{References}

"Fact File." 1990. The Chronicle of Higher Education, 24 January, p. A33.

Astin, Alexander W., K. C. Green and W. S. Korn. 1987. The American Freshman: Twenty Year Trends, 1966-1985. Los Angeles: Cooperative Institutional Program, Higher Education Research Institute, Graduate School of Education, University of California at Los Angeles.

Bowen, William G. and Julie Ann Sosa. 1989. Prospects for Faculty in the Arts and Sciences. Princeton, NJ: Princeton University Press.

El-Khawas, Elaine. 1989. Campus Trends, 1989. Washington, DC: American Council on Education.

Heller, Scott. 1990. "The Expected Turnaround in the Faculty Job Market May Come Too Late for 'Lost Generation' of Scholars," The Chronicle of Higher Education, 23 May, pp. A1, 14-15.

McMullen, Liz. 1989. "Cornell Faculty Panel Urges Cuts in Jobs So Pay Can Go Up," The Chronicle of Higher Education, December 6, pp. A25-26.

Mooney, Carolyn J. 1990. "Universities Award Record Number of Doctorates Last Year; Foreign Students Thought to Account for Much of the Increase," The Chronicle of Higher Education, 25 April, pp. $1,11,18$.

Mooney, Carolyn J. 1990. "Faculty Job Market Slowly Improving, Evidence Indicates," The Chronicle of Higher Education, 18 April. 